Rev. Estud. Ling., Belo Horizonte, v. 29, n. 1, p. 289-329, 2021

\title{
Dimensões da violência na linguagem: articulando cenários e perspectivas \\ Dimensions of violence in language: articulating scenarios and perspectives
}

\section{Daniel do Nascimento e Silva}

Universidade Federal de Santa Catarina (UFSC), Florianópolis, Santa Catarina / Brasil Universidade Federal do Rio de Janeiro (UFRJ), Rio de Janeiro, Rio de Janeiro / Brasil dnsfortal@gmail.com

http://orcid.org/0000-0002-6098-5185

Anabella Machado Rocha

Universidade Federal do Rio de Janeiro (UFRJ), Rio de Janeiro, Rio de Janeiro / Brasil bellarocha03@gmail.com

http://orcid.org/0000-0002-0970-0308

Alvaro Monteiro Carvalho Arcanjo

Centro Federal de Educação Tecnológica Celso Suckow da Fonseca (CEFET/RJ), Valença, Rio de Janeiro / Brasil

Universidade Federal do Rio de Janeiro (UFRJ), Rio de Janeiro, Rio de Janeiro / Brasil alvaro.monteirocarvalho@yahoo.com.br

http://orcid.org/0000-0003-0412-6500

Clarissa Rodrigues Gonzalez ${ }^{1}$

Universidade Federal do Rio de Janeiro (UFRJ), Rio de Janeiro, Rio de Janeiro / Brasil gonzalezclariss@yahoo.es

http://orcid.org/0000-0002-3521-897X

\footnotetext{
${ }^{1}$ Boslsista de Doutorado - Comissão de Aperfeiçoamento de Pessoal de Ensino Superior (CAPES). 
Resumo: Este artigo tem como objetivo discutir dimensões da violência em três contextos empíricos em que as facetas física e simbólica da violência diferentemente se manifestaram: um relato de uma mulher vítima de violência sobre sua tentativa de realizar um boletim de ocorrência sobre ameaças sofridas pelo então marido; as declarações de um executivo sobre o pouco valor da vida de favelados no contexto da pandemia de Covid-19; uma capa jornalística em que a cabeça da ex-presidenta Dilma Rousseff aparece em chamas. $\mathrm{O}$ artigo invoca os conceitos de escala, comunicabilidade e indexicalidade para produzir sentido sobre como a violência foi percebida e enquadrada no primeiro contexto, sobre como ela circulou viralmente no segundo e sobre como ela participou da semiotização e contextualização de uma imagem no terceiro. Metodologicamente, o artigo combina abordagens etnográficas e documentais, diferentemente empregadas em cada contexto empírico. Além de promover uma discussão situada dessas três manifestações da violência, apontamos para formas de resistência à violência, algumas delas inscritas na própria produção da atividade reflexiva sobre a manifestação e os efeitos da violência.

Palavras-chave: escalas; comunicabilidade; indexicalidade; violência empírica; violência simbólica.

Abstract: This article aims at discussing dimensions of violence in three empirical scenarios in which physical and symbolic violence differently surfaced: an account of a female victim of violence about her attempt to press charges about threats made by her then husband; the comments by a businessman about the lack of value of the lives of favela residents in the context of the Covid-19 pandemics; a newspaper cover displaying the head of the former Brazilian president Dilma Rousseff on fire. The article builds on the concepts of scales, communicability and indexicality in order to render intelligible the ways in which violence was perceived and framed in the first context; in addition to how it virally spread in the second, and to how it participated in the semiotization and contextualization of an image in the third. Methodologically, the paper combines ethnographic and documental approaches, and applies them differently in each empirical context. In addition to providing a situated discussion of these three manifestations of violence, we point to modes of resistance to violence, some of which are inscribed in the very production of reflexive activity about the manifestation and effects of violence.

Keywords: scales; communicability; indexicality; empirical violence; symbolic violence.

Recebido em 18 de junho de 2020

Aceito em 03 de setembro de 2020 


\section{Violência, linguagem e resistência}

Este artigo aborda diferentes dimensões da violência em três cenários empíricos diferentes. Os cenários são: o relato de uma mulher vítima de violência doméstica sobre sua tentativa de denunciar o agressor em uma delegacia; as declarações de um executivo sobre o pouco valor da vida de favelados no contexto da pandemia de Covid-19; uma capa jornalística em que a cabeça da ex-presidenta Dilma Rousseff aparece em chamas. Nosso principal objetivo é oferecer uma reflexão situada sobre a relação entre violência e significação, em especial sobre como os participantes produzem sentido sobre violência e seus efeitos, no primeiro cenário; sobre como as palavras que ferem participam de um processo de comunicabilidade (BRIGGS, 2005) ou circulação infecciosa, no segundo cenário, e sobre a força do enquadramento da imagem fotográfica na produção de violência contra uma mulher, no terceiro cenário.

A literatura especializada sobre o tema da violência tem apontado que, apesar de sua natureza destrutiva e desorganizadora, a violência mantém estreitas relações com a produção de significado (ver BUTLER, 1997; CALDEIRA, 2000; SCARRY, 1987; SILVA, 2017). Butler (1997, p. 4), por exemplo, argumenta que "ser ferido pela fala é sofrer uma perda de contexto, isto é, não saber onde você está" (tradução nossa). A autora complementa que a violência na linguagem coloca o sujeito que foi endereçado violentamente "fora de controle. A capacidade de circunscrever a situação do ato de fala é obliterada no momento da enunciação injuriosa" (p. 4, tradução nossa). Há, além disso, evidências empíricas de que o silêncio e a desarticulação enunciativa podem resultar da violência: Primo Levi (1988) testemunha que, em campos de concentração, alguns sujeitos tornavam-se mudos, solitários, destituídos de laços comunicativos com os outros; Veena Das (2007, p. 87-91) elabora sobre o caso de Manjit, uma mulher que, vitimizada por sucessivos ataques e estupros no contexto da violência da Guerra da Partição entre Índia e Paquistão, ficou desarticulada e incapaz de verbalizar. Não obstante essa destruição do significado, o ato violento em si tende a ser direcionado, regrado e ordenado. Violência simbólica e física também extrapolam sua dimensão "irracional" ao revelarem dimensões semióticas em seu desdobrar no espaço e no tempo: na violência genocida em Ruanda, por exemplo, as varas com as quais as pessoas da etnia tutsi eram empaladas tinham uma altura que variava entre $1,80 \mathrm{~m}$ e $2 \mathrm{~m}$ - o equivalente à altura 
de um tutsi (ver MALKKI, 1995, p. 92). Atos de terror e violência são, portanto, situados em sistemas de símbolos.

A reorganização prática e psíquica daqueles que sofrem a violência é também regida por regras - por exemplo, sujeitos podem criar redes de solidariedade para narrar o trauma e buscar possibilidades de cura (FREUD, 1920); Estados fraturados pela violência podem estabelecer comissões da verdade e projetos de reconciliação (VERAS, 2011). Por mais que desorganize indivíduos e comunidades, "a experiência da violência sempre provoca mudanças" (CALDEIRA, 2000, p. 28), e o ato posterior de narrar, falar, em suma, tornar o ato violento como símbolo tem consequências performativas diversas - muitas das quais contrárias à própria violência.

Dada essa relação entre violência, sentido e sobrevivência à violência, propõe-se aqui uma reflexão redigida por quatro autores/as interessados/as em criar inteligibilidade sobre essas relações no Brasil contemporâneo. Mais especificamente, propomos uma comparação de nossos objetos de pesquisa com vistas a endereçar questões relevantes no campo dos estudos sobre a violência e significação: Que dimensões ou escalas a violência assume quando generificada, racializada e territorializada? Como circula a violência no interior da linguagem? Em que medida palavras e imagens violentas são citacionais, isto é, como acumulam e condensam condições de violência vindas de outros espaços e temporalidades? Como os sujeitos podem resistir à violência que os atinge?

Essas questões, obviamente, precisam ser situadas e respondidas no espaço e no tempo. Daí nossa proposta situada de reflexão. A seguir, portanto, delineamos três contextos em que a violência e a resistência a esta são diferentemente instanciados. Na reflexão que se segue, inicialmente apontamos a teoria geral de base, que orientará a compreensão sobre a violência nos cenários empíricos. Na seção seguinte, discutiremos o enredamento da violência em escalas - em dimensões do discurso e da vida social (CARR; LEMPERT, 2016) - no contexto do relato de uma vítima de violência sobre sua tentativa de prestar queixa na delegacia acerca das ameaças que vinha sofrendo do então marido. Em seguida, partimos para o tema da circulação da violência no discurso, mais especificamente no contexto da violência simbólica contra pessoas negras e moradoras de periferia, durante a intensa circulação de discursos sobre a pandemia de Covid-19 no Brasil. Na seção seguinte, retornamos à violência contra a mulher, elaborando sobre a dimensão semiótica 
da violência simbólica contra Dilma Rousseff durante o processo de impeachment por ela sofrido. Finalmente, apresentamos as considerações finais, em que comparamos os três contextos empíricos.

\section{Base teórica}

Embora a teoria que fundamenta a presente reflexão seja, em grande parte, apresentada à medida que realizamos as análises dos contextos empíricos, convém aqui ressaltar a perspectiva teórica comum às abordagens empíricas da violência que apresentaremos adiante. A proposta teórica mais ampla é aquela que encontra sua melhor expressão na formulação de John L. Austin de que a linguagem não é mera representação de um mundo exterior e independente, mas sim uma forma de ação neste mundo (AUSTIN, 1962). Como a extensa e frutífera pesquisa de Rajagopalan (2010) apontou, Austin ofereceu as bases para uma visão performativa da linguagem. Em sua reflexão indômita e cuidadosa, Austin apontou que a fronteira entre os performativos e os constativos - termos que ele próprio inventou - são muito tênues, de forma que o constativo, aquele enunciado que verifica um estado de coisas no mundo, passa a ser um tipo de performativo - isto é, aquele enunciado verdadeiro (ou falso) que foi confirmado (ou desautorizado) como tal (ver MEY, 2001). Como Latour e Wolgar (1997) demonstrariam em sua etnografia da ciência, um enunciado verdadeiro na ciência precisa ser "autenticado" como verdadeiro: uma proposição em um artigo científico, por exemplo, passa por uma longa cadeia de verificação, teste e autenticação por pares e pelas instituições que irão aferir a esse enunciado o status de "verdadeiro" ou "falso". Duranti (1997), baseado em sua etnografia da linguagem com samoanos, viria a concluir que a "verdade é uma conquista interacional" (p. 230, tradução nossa). A especificação da tese de Austin neste artigo é a de que, se a linguagem é uma forma de ação, essa ação pode ser violenta.

Outro construto fundamental para os três trabalhos aqui comparados é o de indexicalidade. Em sua forma mais básica, a indexicalidade pode ser compreendida como o "meio pelo qual, em diferentes níveis, signos linguísticos ou outros direcionam os usuários desses signos às condições envolventes específicas em que esses usuários os utilizam" (SILVERSTEIN, 2006, p. 14, tradução nossa). Embora o conceito não seja explicitado em todas as análises, ele subjaz a todas elas, na medida em que compartilhamos a visão de que indexicalidade 
é pragmática (SILVERSTEIN, 1993). As análises que apresentaremos sobre a narrativa de uma vítima da violência, sobre a violência simbólica que circula numa live do Estadão e sobre a violência explicitamente gráfica produzida pelo mesmo veículo jornalístico são realizadas de forma a evidenciar a indexicalidade desses eventos e das camadas e cadeias de outros eventos neles encaixadas. Trata-se, em resumo, de mostrar como os signos utilizados indexicalmente - isto é, pragmaticamente pressupõem certos contextos e, ao mesmo tempo, afetam tais contextos (ver SILVERSTEIN, 2006).

Os demais conceitos mais salientes - escala e comunicabilidade - serão detalhados adiante. Por ora, no entanto, antecipamos que escala, segundo Marilyn Strathern (2004, p. XV), pode ser definida como "a organização de perspectivas sobre objetos de conhecimento e investigação". Esse conceito, bastante central para campos como a geografia e a antropologia, tem recebido atenção crescente dos estudos da linguagem. Na obra recente, Scales: Discourse and Dimensions of Social Life (Escalas: Discurso e Dimensões da Vida Social), os estudiosos da linguagem, Summerson Carr e Michael Lempert (2016), explicam que escalas se referem aos processos por meio dos quais perspectivas e compreensões acerca de processos sociais e de nós mesmos são forjadas em nossas práticas interacionais. De acordo com os autores, escalas ajudam as pessoas a orientarem suas ações e organizar suas experiências e, com efeito, funcionam como alicerce da maneira como nos engajamos em práticas semióticas diversas. Atividades escalares são aquelas em que os atores sociais realizam ações como medir, pesar, comparar objetos ou grupos de objetos de forma a torná-los socialmente significativos. Comunicabilidade, por seu turno, é um processo metapragmático ${ }^{2}-$ isto

\footnotetext{
${ }^{2}$ A partir da noção de metalinguagem discutida por Jakobson, seu orientador de doutorado, Silverstein (1993) propõe o termo 'metapragmática' para se referir à imaginação realizada pelos usuários da pragmática do discurso. Para Silverstein, a metapragmática anda lado a lado da pragmática. A função metapragmática arregimenta os índices do discurso em "eventos interpretáveis de tal-e-tal tipo que a língua em interação constitui ([e] na qual consiste)" (SILVERSTEIN, 1993, p. 37). No limite, para Silverstein, compreender é compreender metapragmaticamente: "Compreender a interação discursiva como evento de tal-e-tal tipo é precisamente ter um modelo de texto interacional" (p. 37). Neste artigo, utilizamos 'metapragmática' nesse sentido proposto por Silverstein e preferimos não fazer distinção entre esse termo e 'metalinguagem', 'metadiscurso' ou 'metacomunicação'.
} 
é, um processo de imaginação da pragmática do discurso - por meio dos quais os participantes criam modelos da produção, circulação e recepção dos discursos (BRIGGS, 2007). Briggs faz um trocadilho como o termo 'comunicável', que em medicina se refere a doenças que são transmissíveis, e com a noção de 'comunicação', em certas formações ideológicas, como processo transparente e linear. Comunicabilidade seria, em sua forma mais básica, a imaginação sobre a infecciosidade dos textos, os quais, em sua viralização social, carregariam informação transparente sobre o mundo. Como Briggs (2007) argumenta, certos textos são mais infecciosos e penetram mais rapidamente o tecido social, espalhando-se e comunicando-se entre as pessoas com muito mais facilidade. Em linhas gerais, certas ideologias são extremamente "contagiosas" e viajam mais intensamente por diferentes tempos-espaços, projetando certas ideias acerca do mundo como representações fiéis e verídicas da realidade e, como tal, possibilitam o tráfego de certas crenças como transparentes, neutras, livres de ideologias (BRIGGS, 2007).

Passemos, adiante, aos contextos em que a violência se manifestou.

\section{Escalas da violência}

O primeiro contexto empírico que trazemos para reflexão gira em torno da própria definição para os participantes de uma interação do que seja violência. Apresentaremos inicialmente o dado de pesquisa, para em seguida elaborarmos teoricamente sobre ele. $O$ dado em questão foi extraído da pesquisa de campo de Alvaro Arcanjo, que, durante os anos de 2017 e 2018, realizou, em uma cidade de pequeno porte do interior do Rio de Janeiro, uma etnografia com mulheres vítimas de violência, com ativistas e com agentes do Estado responsáveis pelo atendimento a essas vítimas (ARCANJO, pesquisa em andamento). ${ }^{3}$ A narrativa abaixo

\footnotetext{
${ }^{3}$ A pesquisa foi registrada e aprovada na Plataforma Brasil, com registro CAAE sob o número 19121119.0.0000.8160. Os/As participantes da pesquisa assinaram um Termo de Conhecimento Livre e Esclarecido, que esclarecia os objetivos da pesquisa, bem como assegurava o anonimato de seus participantes, conforme as resoluções 466/12 e 510/2016 do Conselho Nacional de Saúde. Aos/Às participantes também foi garantida a retirada dos dados de entrevistas em caso de desistência, com a consequente destruição do material fornecido. No comitê de ética, esclareceu-se que um dos potenciais prejuízos da pesquisa é a rememoração de experiências traumáticas, o que poderia ser compensado pelo benefício de expor para a sociedade tais problemas e buscar modos de ressignificação.
} 
é o excerto de uma entrevista em que Cecília, ${ }^{4}$ mulher negra, de 54 anos, moradora de um bairro pobre dessa cidade, relata ao pesquisador uma cena por ela vivida quando procurou uma delegacia para registrar um boletim de ocorrência relativo a ameaças feitas pelo marido.

\section{Excerto 1}

01 Cecília Ele muito enjoado, eu peguei, lá no baile, ele

02

03

04

05

06

07

08

09

começou a falar, aí nós viemos embora, aí ele começou falar as coisas comigo, me ameaçar, aí eu peguei, no outro dia eu peguei e fui lá dar parte dele levei até a faca, uma faca que ele tinha amolado falando que ia me matar, o- o rapaz que tava lá o delegado sei lá o que que é, falou comigo, na frente dele, falou na frente dele, você guarda isso, não deixa nem ele ver, porque vai pôr no lugar onde você tirou pra ele não ver, porque deixa lá

\section{Alvaro Falando para você}

Cecília Porque não vai adiantar nada, falando comigo, não vai adiantar nada você é: : é mostrar isso aí

Alvaro Mas ele explicou

Cecília Isso não adianta nada

Alvaro Ah

Cecília Eu falei com ele mas é a faca que ele me ameaçou, aí ele falou assim isso aí não vai dizer nada guarda isso, põe no mesmo lugar que você tirou para ele não saber que você mexeu, aí, aí depois ele- ele virou, aí eu falei assim, mas ele me ameaçou me xingou, aí o rapaz falou assim, mas a senhora tá com ele ainda? na frente dele, tô, mas você vai me desculpar a mais sem vergonha é você de ainda tá com ele hoje

Isso o rapaz da delegacia falou com a senhora na frente dele?

\footnotetext{
${ }^{4} \mathrm{O}$ nome dos participantes da etnografia e da cidade foram alterados ou omitidos com vista à manutenção do anonimato dos sujeitos da pesquisa. Na transcrição de dados de fala, optamos por utilizar símbolos da escrita, mantendo, na medida do possível, o ritmo da fala. Utilizamos convenções mínimas para marcar fenômenos da fala:

:: alongamento de vogal (ex. é::)

- hesitação (ex. ele- ele).
} 
29 Cecília $\mathrm{Na}$ frente dele, mais sem vergonha é você, a 30 senhora está com ele até hoje, eu falei mas eu, 31 meus filhos não temos pra onde ir, aí ele falou, 32 então você aguenta as, as consequências então 33 aguenta o homem que tem, aí ele pegou e olhou 34 para mim, rindo do delegado, fala isso comigo, delegado, sei lá o que que é

\section{Alvaro [...]}

Cecília É tá tudo guardado comigo lá, aí ele falou, aí ele virou para esse rapaz e falou assim, viu é isso aí que eu falo com ela tá comigo porque ela quer, ninguém tá mandando, ela ficar comigo

Nesta narrativa, Cecília relata inicialmente que foi ameaçada pelo então marido depois de um desentendimento dos dois em um baile. Ela conta que depois procurou uma delegacia para prestar queixa da ameaça, levando consigo uma faca que o marido tinha utilizado para ameaçá-la. $\mathrm{Na}$ delegacia, ela conta que o inspetor de polícia mostrou-se pouco receptivo ao seu relato, discordou que a faca por ela levada serviria como prova da ameaça e, além disso, culpou-a por não ter deixado seu marido: "mas você vai me desculpar a mais sem vergonha é você de ainda tá com ele hoje" (linhas 24-26). Ela fala, então, sobre a dificuldade de deixá-lo em face de sua situação econômica: "eu falei mas eu, meus filhos não temos pra onde ir" (linhas 30-31), ao que o inspetor responde, segundo Cecília: "então você aguenta as, as consequências, então aguenta o homem que tem" (linhas 32-33). No excerto em tela, Cecília também dá a entender que seu marido a acompanhou na visita à delegacia: ela fala por exemplo que o (inspetor) "falou comigo na frente dele" e que seu marido, ao final, "virou para esse rapaz e falou assim, viu é isso aí que eu falo com ela tá comigo porque ela quer, ninguém tá mandando, ela ficar comigo" (linhas 38-40).

A priori, é importante entender a situação interacional em que este dado foi gerado, a própria complexidade de narrar a violência e os meandros institucionais do atendimento à mulher vítima de violência nessa cidade para que algumas lacunas na narrativa possam ser preenchidas. As lacunas são: o fato de Cecília relatar a ameaça a um inspetor de polícia homem (e não a uma mulher, em linha com o padrão das delegacias de atendimento à mulher, conforme descrito, por 
exemplo, em OSTERMANN, 2003) e a aparente inconsistência de o agente da violência (o então marido) estar acompanhando a vítima em seu relato. Em primeiro lugar, essa interação se deu no contexto das onze entrevistas que foram geradas por Arcanjo durante sua etnografia. Cecília foi apresentada ao autor por uma amiga, que sabia do seu interesse de pesquisa e também ofereceu sua casa como um lugar seguro para a realização desta e de futuras entrevistas. Assim, a interação foi um esforço de criar condições para que uma mulher que sofrera violência doméstica narrasse sua experiência num contexto de efetiva escuta de seu sofrimento. Em segundo lugar, narrar a experiência com a violência - em linha com a atividade de narrar de modo mais amplo - é uma estratégia de orientação em relação a eventos ocorridos em outras temporalidades (ver DE FINA, 2003; FABRÍCIO, 2006).

O relato de Cecília pode ser visto também como testemunho, cuja narrativização constitui o enlace entre memória e história (SELIGMANNSILVA, 2017). Olhando por essas lentes, o que Cecília conta não é um acesso direto aos "fatos". Pelo contrário, a atividade narrativa-testemunhal da participante emerge dos destroços e ruínas deixados pela violência que sofreu e diz respeito a um trabalho criativo que reúne e relaciona fragmentos da história na reconstrução de suas vivências (SELIGMANNSILVA, 2017). Vejamos: ao contar histórias, sempre nos engajamos em uma tarefa reflexiva para organizar o que contar, como contar, como e onde começar e terminar, que eventos, espaços e tempos privilegiar. Novamente, não se trata de um espelhamento de uma realidade. Como apontamos, a linguagem não espelha o mundo (AUSTIN, 1962), tampouco o faz a narrativa. Os estudos sobre narrativa, "[m]ais do que perscrutar por uma verdade imanente e natural dos acontecimentos e da vida das pessoas, (...) destacam que a experiência se torna significativa e acessível ao ser narrada pelos sujeitos [...]" (LOPES et al., 2019, p. 34).

Além disso, a história narrada "só pode ser conhecida ao ser interpretada, (re)contextualizada e (res)significada pelos próprios pesquisadores" (LOPES et al., 2019, p. 34). Em razão do caráter performativo da linguagem, Fabrício (2006, p. 191) explica que a narrativa "reúne eventos contingentes, imputa-lhes uma lógica causal explicativa, arrumando-os segundo uma ordem espaço-temporal". Assim, a narrativização é um processo performativo de orientar, de perspectivar, de dimensionar segundo parâmetros espaço-temporais, determinado aspecto daquilo que compreendemos e chamamos de realidade. Nesse 
sentido, a menção que Cecília faz ao então marido na visita à delegacia é inconsistente apenas se olharmos para o excerto em questão como uma totalidade em si mesma. Cecília estava, ao contrário, produzindo sentido sobre as fraturas que a violência do marido havia causado em sua vida. Além disso, o marido tinha o hábito de persegui-la, conforme relatado pela moça em momento posterior da entrevista, o que parece indicar que ele a tinha seguido até o local.

A presença pouco usual do agente da violência no relato em questão se liga à segunda complexidade da situação de interlocução narrada: o fato de Cecília ser atendida por um homem e não por uma policial mulher. Em sua etnografia, Arcanjo aponta que, devido ao seu número de habitantes (76.000) e de registros de casos de violência contra a mulher, a cidade em questão não tem uma Delegacia de Atendimento à Mulher, mas sim um Núcleo de Atendimento à Mulher (NUAM), que fica localizado no segundo andar da delegacia de polícia civil que Cecília visitou. Assim, o "andar de baixo" da delegacia funciona como uma certa triagem para o "andar de cima", onde ficam as oficiais de polícia do NUAM. Embora sejam as policiais femininas as responsáveis pela condução de investigação de crimes contra a mulher, há casos (quando o NUAM não está aberto, por exemplo) em que policiais homens fazem o primeiro atendimento. Em entrevista a Arcanjo, um delegado da cidade deu um pouco mais de nuance à questão:

\section{Excerto 2}

o NUAM são policiais femininos policiais civis,
investigadores e inspetores que atende exatamente
essa demanda né, às vezes o registro é feito por
um policial masculino mas o trabalho de investigação
toda o atendimento aquela (...) é o lado social, você
também tem que ver o lado social o lado policial é
feito pelo policial feminino tá

Dadas essas considerações, agora passemos à questão de que a violência no Excerto 1 está enredada em múltiplas dimensões - históricas, situacionais, diferenciais. Aqui, aprofundaremos o conceito de escalas (CARR; LEMPERT, 2016), previamente definido, para entender essas dimensões da violência narrada por Cecília (e presentes no discurso do então marido e do oficial de polícia que atende Cecília). Para Carr e Lempert (2016), escala diz respeito aos processos de perspectivação, 
dimensionamento, categorização e avaliação que constituem formas de perceber, de dizer e de agir. Muitas dessas formas de perceber-dizer-fazer são reiteradas em nossas práticas semióticas e cristalizam certos pontos de vistas que acabam por orientar as pessoas nos processos de construção de sentidos (MOITA-LOPES; FABRÍCIO; GUMARÃES, 2019). Não existiria, segundo Carr e Lempert (2016), conhecimento produzido fora de trabalhos escalares. Mobilizar projeções escalares envolve um trabalho semiótico bastante intenso: ancorar espaço-temporalmente, nomear, comparar, fazer analogias, mensurar, agrupar, diferenciar, criar oposições binárias, classificar/categorizar, territorializar (pessoas, comunidades, regiões, fenômenos sociais, línguas etc.), generalizar, expandir, limitar etc. (CARR; LEMPERT, 2016). Nesse sentido, nossas práticas de linguagem não ocorrem em um vácuo, não são lisas nem autônomas. Isso implica dizer também que, mesmo não tendo controle sobre os efeitos de nosso dizer, nossas produções discursivas são sempre orientadas ideologicamente, são ações performativas, que constroem posições sociais e engendram modos de dizer-fazer-perceber que, na repetição, se naturalizam. Com efeito, as escalas não são instâncias dadas, isto é, não preexistem ao discurso. Pelo contrário, nós utilizamos recursos semióticos diversos ao criar projetos escalares acerca do mundo ao nosso redor a partir de uma série de estratégias - como comparação, dicotomização, categorização, tracejo de distinções, hierarquizações, criação de binarismos e identidades etc. - que tem alto poder performativo. Em resumo, a (re)produção e a compreensão de sentidos acerca da realidade como a entendemos são efeitos da mobilização de recursos semióticos que colocam em jogo historicidades sedimentadas e a situacionalidade do nosso trabalho escalar (BLOMMAERT, 2015). É uma atividade semiótica do aqui e do agora que, ao mesmo tempo, incita ressonância de histórias de significação persistentes. Essa concepção é bastante frutífera no trabalho de desnaturalização de sentidos altamente estáveis e nos ajuda a olhar analiticamente para o modo como as pessoas produzem estratégias que guiam o nosso perceber-dizer-fazer (GONZALEZ; MOITA-LOPES, 2020).

A partir dessa perspectiva, o entendimento de uma dada ação como violenta ou não, como merecedora de atenção por parte do Estado ou não, é dependente da orientação ideológica a que os participantes da interação se alinham. Assim, Cecília busca a delegacia para fazer valer o direito de proteção a mulheres vítimas da violência. A Lei 11.340/2006 
(BRASIL, 2006), também conhecida como Lei Maria da Penha, versa sobre a criação de mecanismos para se combater casos de violência doméstica e familiar contra a mulher e tem como objetivo a proteção de mulheres contra vários tipos de violência, que vão, inclusive, além da violência física. Contrariamente à determinação da lei, Cecília é desencorajada pelo inspetor de plantão a efetuar o registro de ocorrência contra seu então marido. Um poderoso processo escalar está em jogo, ecoando significações persistentes no Brasil, muitas delas documentadas em pesquisa acadêmica.

Como a extensa pesquisa sociolinguística de Ana Ostermann e suas colaboradoras têm demonstrado, o atendimento em Delegacias Especializadas em Atendimento à Mulher é informado por ideologias, assimetrias e dinâmicas de poder na condução do processo de atendimento às vítimas da violência que terminam por somar-se ao sofrimento das vítimas. Em sua etnografia em uma delegacia da mulher numa cidade do Sudeste do Brasil, Ostermann (2003) conclui que os encontros por ela documentados nesta delegacia da mulher "são caracterizados, na sua esmagadora maioria, pelo elevado grau de controle das agentes policiais sobre as interações, bem como pela distância em relação às vítimas" ( $p$. 497-498, tradução nossa). A autora identifica que as agentes de polícia "atendem claramente menos às necessidades e desejos das vítimas (ou seja, sua face [no sentido de GOFFMAN, 1955]), fornecendo mínimo ou nenhum feedback quando as vítimas denunciam os seus problemas." (p. 498). Ostermann (2003) compara os padrões interacionais do atendimento a vítimas de violência na Delegacia da Mulher com um centro feminista de atendimento à mulher (CIV-Mulher), localizado na mesma região, e percebe que, comparativamente, as oficiais da delegacia da mulher apresentam um índice alto de silêncio ao fim dos turnos no relato das mulheres (29\% na delegacia, versus $7 \%$ no CIV-Mulher), um número menor de continuadores, como 'ahãm', ' $h m m m$ ', que tendem a marcar interesse pela conversa ( $7 \%$ na delegacia versus $29 \%$ no CIVMulher) e um alto índice de mudança de tópico nas respostas (23\% na delegacia versus 6\% no CIV-Mulher). Vistos no todo da etnografia de Ostermann, que conviveu com as oficiais da delegacia e as triagistas do CIV-Mulher, esses padrões interacionais se associam a questões de poder, afiliação e habitus nas comunidades de prática de que essas mulheres participam: enquanto a orientação feminista no CIV-Mulher tendia a escalar a interação entre triagista e vítima da violência para um nível mais 
horizontal e participativo, o distanciamento das policiais de uma postura feminista e as características do "mercado simbólico" (BOURDIEU, 1991) da polícia civil - uma instituição de maioria masculina, hierárquica e calcada no terreno das desigualdades brasileiras - levavam essas agentes de Estado a demonstrarem menos solidariedade às vítimas da violência.

Em estudo mais recente, Ostermann e Costa (2012) verificam um padrão avaliativo no atendimento na delegacia da mulher semelhante ao relatado por Cecília. Lembremos que Cecília relata ter sido recriminada pelo inspetor de polícia por não ter se separado do marido ainda: "a mais sem vergonha é você de ainda tá com ele". Nos termos da Análise da Conversa, este é um tipo não preferido de resposta em interações solidárias; quando uma pessoa faz um comentário negativo sobre si mesmo, por exemplo, a tendência preferida de um interlocutor que se identifica com essa pessoa é negar o comentário, em linha com o princípio da proteção da face dos participantes da interação (ver BROWN; LEVINSON, 1987; OSTERMANN; COSTA, 2012).

No Excerto 1, o inspetor, além de se negar a registrar a ocorrência de violência do então marido de Cecília, realiza uma ofensa ao reciclar um juízo moral, lançando mão do recurso "sem vergonha" para caracterizála. Em uma cadeia de iterabilidade (DERRIDA, 1991), essa expressão cita outras abordagens parecidas, deslocadas de outros espaços-tempos e condensadas no momento da injúria (ver BUTLER, 1997; SILVA, 2012). Em linha com o padrão percebido por Ostermann, o local que deveria ofertar serviço de proteção para Cecília reitera discursos patriarcais, produzindo violência simbólica adicional contra a vítima. Nos termos de De Lara et al. (2016, p. 174), o "sistema funciona, então, como uma continuidade da violência sofrida pela mulher no espaço privado, vítima de seu marido, pai, companheiro, chefe. A mulher recorre ao Estado buscando refúgio e é novamente violentada" (itálico no original). $\mathrm{O}$ ato de fala "a mais sem vergonha é você" alude a discursos sexistas que atuam na construção de vítimas de violência como culpadas (SAFFIOTI, 2004). Nessa lógica, como Cecília é "sem vergonha", ela merece apanhar do marido. Esse é modus operandi da culpabilização da mulher pelo estupro e por outras formas de violência (DE LARA et al., 2016).

A questão central relativa ao Excerto 1, portanto, diz respeito ao fato de que a violência está enredada em escalas ou dimensões da vida social. Ou seja, o inspetor de polícia encaixa ou escala a ação verbal do aqui-agora em certos modos convencionais de compreender 
a desigualdade brasileira. Assim, sua ação da indiferença, produtora de condições para o silenciamento da violência contra a mulher, aponta para projetos escalares específicos no Brasil - por exemplo, a matriz escalar patriarcal, que "mensura" a ação feminina de conviver com um parceiro violento como "sem-vergonhice". Além disso, essas construções escalares baseadas em discursos de culpabilização da vítima reiteram condições metapragmáticas (como as narradas por Cecília e por Ostermann (2003)) que impedem muitas mulheres de acessarem o Estado.

$\mathrm{Na}$ próxima seção, discutiremos que essas formas de escalar a violência - ou seja, de encaixar o aqui-agora da interação em uma matriz dominante, que desigualmente organiza percepções sobre pertencimentos identitários legítimos - se ligam a padrões de circulação do discurso. Sigamos.

\section{Circulação da violência}

$\mathrm{Na}$ seção anterior, olhamos para um relato da violência e discutimos a natureza escalar ou multidimensional da violência. Aqui, nos perguntamos: como circula a violência na linguagem? Partimos do influente trabalho do antropólogo e linguista Charles Briggs (2005, 2007, 2011) para dar sentido à noção de que, assim como os vírus, a violência que circula na linguagem é infecciosa e produz, à medida que circula, compreensões sobre o próprio processo de infecção. Por exemplo, como um vírus, o ato de violência simbólica "a mais sem vergonha é você" vem de um espaço-tempo anterior ao do inspetor de polícia e certamente infectará outros, contribuindo para a manutenção desse processo de naturalizar vítimas da violência como culpadas. Para dar nuance a esse modelo de compreensão da violência como infeccioso e metacomunicativo, enfocaremos nesta seção a viralização da violência simbólica contra negros e moradores de periferia no contexto de uma viralização que nos afeta a todos, a pandemia de Covid-19.

O mundo vive uma pandemia. A Covid-19 expande-se por todos os continentes, deixando um rastro de sofrimento, miséria e morte. Foi em 31 de dezembro de 2019 que a China anunciou o surgimento de casos de pneumonia na cidade de Wuhan, província de Hubei. Uma semana depois, em 7 de janeiro de 2020, as autoridades chinesas alertaram a OMS sobre a identificação de uma nova cepa de coronavírus que ainda não havia sido detectada em humanos. Em 30 de janeiro de 2020, já se constituía numa 
Emergência de Saúde Pública de Importância Internacional e, menos de dois meses depois, em 11 de março de 2020, a OMS declarou o Covid-19, infecção causada pelo novo coronavírus, como uma pandemia.

De acordo com os dados do Ministério da Saúde, no dia 30 de agosto de 2020, o Brasil alcançou a marca de 3.862.311 infectados e 120.828 óbitos causados pela Covid 19, ocupando o segundo posto global em número de casos confirmados, ficando atrás apenas dos Estados Unidos da América. ${ }^{5}$ Vale ressaltar que no Brasil a subnotificação é alta e o Executivo tentou esconder os números de casos, o que gerou reações negativas diversas. $\mathrm{O}$ novo coronavírus mostra, com a rapidez que se dissemina e infecta, sua implacável potência de comunicabilidade. A disseminação da Covid-19 se dá de pessoa a pessoa pela projeção de perdigotos do nariz ou da boca. Os perdigotos contaminados não se projetam para além de dois metros, mas podem permanecer sobre as superfícies em que caem por até 72 horas, aguardando o próximo a ser contaminado ao tocá-los e conduzi-los ao nariz, boca ou olhos, criando um contexto de contaminação que impulsiona a disseminação, dispensando a presença física do infectado para o contágio. O novo coronavírus "pegou carona" e viajou por mar, terra e ar para alcançar todos os continentes. Minúsculo, avança sobre as populações sem distinguir seu alvo, mas se favorece das condições de desigualdade social e econômica criadas pelas sociedades humanas e encontra no mundo globalizado as condições ideais para se expandir. Não sendo tão letal como outros vírus que já assustaram a humanidade, como o Ebola, por exemplo, ele consegue construir o que precisa, tempo e condições para contaminar. Muitos já infectados podem apresentar sintomas leves ou mesmo ser assintomáticos, transformandose em seu veículo de transporte. Invisível, o vírus transforma suas vítimas em seus principais aliados para alcançar o seu objetivo, circular para infectar.

A pandemia da Covid-19 surge e acontece num mundo afogado em informações. As novas tecnologias de comunicação e o ambiente virtual das redes sociais são um contexto potencializador de crescente aceleração em que circulam narrativas violentas sobre a desigualdade na pandemia, num processo de intensa contaminação de visões de mundo, ideologias e perspectivas de realidades.

\footnotetext{
${ }^{5}$ Dados da COVID 19 no Brasil. (BRASIL, 2020a) Disponível em: https://susanalitico. saude.gov.br/extensions/covid-19_html/covid-19_html.html. Acesso em: 30 ago. 2020.
} 
O processo de viralização da Covid-19, a um só tempo biológico e social, tem algum paralelo com a noção de 'comunicabilidade' processo de infecção pela linguagem teorizado por Charles Briggs. Em suas abordagens críticas para explorar como a poética e as construções sociais da linguagem, comunicação e mídia estruturam e são estruturadas pela vida cotidiana em zonas de racialização, poder, perigo e, muitas vezes, morte, Briggs (2005) desenvolveu uma perspectiva analítica que se detém sobre a comunicabilidade: processos de construção social da produção, circulação e recepção do conhecimento e do discurso. $\mathrm{O}$ conceito de comunicabilidade inicialmente faz um jogo de palavras com o termo 'comunicável': segundo os dicionários, a acepção mais geral de comunicável remete àquilo que é transmissível em palavras, ecoando ideologias linguísticas sobre a comunicação como processo transparente; como segunda acepção, em medicina, comunicável é o adjetivo utilizado para vírus e bactérias contagiosas ou infecciosas (ver MICHAELIS, 2020; OXFORD, 2020). Assim, comunicabilidade é o processo em que discursos se tornam infecciosos e carregam ideologias linguísticas consigo, muitas das quais calcadas em crenças de linguagem como ato transparente, homogêneo e linear. Briggs trata da comunicabilidade como a forma contagiosa pela qual textos e discursos se disseminam, tornando socialmente significativas determinadas ideologias, concepções de mundo e formas de vida, por vezes mapeando-as como naturais e negando ou silenciando outros pontos de vista. A comunicabilidade funciona dentro do que Bourdieu (1993) chama de campos sociais: "áreas de organização social que produzem papéis sociais, posições, agência e relações sociais que moldam (sem determinar) como os indivíduos e as coletividades são por eles interpelados e os ocupam" (BRIGGS, 2007, p. 556; ver também HANKS, 2008, p. 43-48).

Dado esse cenário, consideremos a declaração dada por Guilherme Benchimol, um integrante do seleto grupo de bilionários brasileiros, presidente da XP Investimentos, em entrevista ao vivo para o jornal $O$ Estado de S. Paulo no dia 5 de maio de 2020, quando emitiu sua opinião sobre a pandemia de Covid-19 no Brasil: "Acompanhando um pouco os nossos números, eu diria que o Brasil está bem.” (ESTADÃO, 2020). Nesse mesmo dia, o Ministério da Saúde, em seu site oficial, notificava 114.715 casos confirmados e 7.921 mortes, tendo ultrapassado a marca de 600 casos/dia (BRASIL, 2020b). E acrescentou o economista: "Nossas curvas não estão tão exponenciais ainda, a gente vem conseguindo 
achatar. Teremos uma fotografia mais clara nas próximas duas a três semanas. O pico da doença já passou quando a gente analisa a classe média, classe média alta. O desafio é que o Brasil é um país com muita comunidade, muita favela, o que acaba dificultando o processo todo."

As opiniões do bilionário presidente da XP constroem uma narrativa que comunica interesses de classe e reproduz índices de uma visão de mundo que compartimentaliza a cidadania brasileira. O Estado de S. Paulo é um tradicional veículo da imprensa corporativa que tem como público alvo os setores de classe alta de São Paulo. A entrevista se deu numa live no Youtube, em programação composta por diversas lives com diferentes personalidades do universo da economia. Esses elementos compõem um campo social de nítidos contornos: com autoridade de bem-sucedido na economia, Benchimol comenta sobre as ações de saúde pública com o recorte que interessa a sua audiência, os de classes média e média alta que estão preocupados com as consequências da pandemia para o sistema financeiro.

Em linha com a pragmática linguística, nossa posição aqui é a de que a linguagem não é um reflexo do mundo "lá fora"; ao contrário, a proposta de Austin (1962) é a de que a linguagem é um modo de agir no mundo. O presidente da XP Investimentos, ao considerar: "(...) eu diria que o Brasil está bem”, mesmo com a divulgação de informações contabilizando milhares de mortes e em tendência crescente, não ignora a realidade, mas situa a realidade nos interesses de seu campo social - "O pico da doença já passou quando a gente analisa a classe média, classe média alta."

Os campos sociais constituem-se no que Briggs chama de cartografias comunicáveis, isto é, "projeções com as quais os textos representam seus próprios pontos de origem, modos de circulação, audiências pretendidas e modos de recepção, contidos no próprio texto" (BRIGGS, 2007, p. 556). Cartografias comunicáveis são também cronotopos (BAKHTIN, 2018), ou seja, recortes de espaço-tempo em que os textos se projetam emergindo tanto de locais particulares como viajando através de locais e atividades específicas. Essas projeções podem se dar em temporalidades diretas e lineares ou em temporalidades múltiplas, como acontece com a Internet. Para Briggs, a ideia de comunicabilidade sugere que o poder dessas cartografias está em mapear processos discursivos particulares e constituir certas dimensões comunicativas e apagar outras, criando subjetividades, relações sociais, 
buscando moldar como as pessoas serão interpeladas nesse processo. Assim, comunicabilidade se refere ao processo como os discursos se constituem em cartografias comunicáveis que estão inseridas nos campos sociais (telejornais, redes sociais etc.), na qual papéis e relações sociais se modelam. A comunicabilidade se refere ainda ao modo como textos viajam espaço-temporalmente, projetando-se por lugares como a televisão e a internet, por meio de gêneros como entrevistas ou postagens digitais, e tendo sua recepção imaginada em certos lugares e posições sociais.

A live do Estadão, assim, é realizada para circular socialmente e carregar consigo projeções sobre como sua audiência deve se posicionar em relação à pandemia. A participação de Benchimol estava situada, portanto, num enquadre metapragmático específico: a série de lives "Economia na quarentena" foi anunciada pelos repórteres de economia do Estadão Fernando Scheller e Monica Scaramuzzo como uma sequência de entrevistas ao vivo "em que empresários e executivos falam das dificuldades de lidar com a crise gerada pela Covid-19". Ao contrário de outras lives na Internet que têm visado discutir a economia de forma mais sistêmica e sobretudo o impacto da crise na imensa parcela de pessoas na informalidade e na precariedade econômica, o Estadão imagina uma cartografia comunicável específica: aquela em que "empresários e executivos" falam - num circuito visto como linear e transparente - para a "sociedade" e para o "Estado".

"O desafio é que o Brasil é um país com muita comunidade, muita favela, o que acaba dificultando o processo todo." Em termos de conteúdo proposicional, esse enunciado de Benchimol indica que as favelas são o "desafio", aqueles territórios que "dificulta[m] o processo todo". Em termos de efeitos pragmáticos, no entanto, esse enunciado diz muito mais. No campo da desigualdade brasileira, as favelas são compostas por uma grande maioria de pessoas negras (IBGE, 2019). A violência da escravidão no Brasil não terminou com a Abolição. O tratamento dado pelo Estado aos descendentes dos escravizados tem a marca da negligência e do controle violento (MACCORD; SOUZA, 2018). Favela e periferia indiciam racialidade, haja vista que a grande maioria dos que as habitam são descendentes dos 350 anos de escravidão negra legalizada e cinco séculos de extermínio dos povos originários do Brasil.

Assim, os enunciados de Benchimol sobre o "problema" da favela podem ser considerados violentos. A violência dessas palavras é diferente da agressão física; trata-se, ao contrário, de uma forma de 
violência simbólica (BOURDIEU, 1991, 2010), insidiosa, que se projeta por cartografias comunicáveis como um modo transparente e bem informado de falar sobre as "dificuldades de lidar com a crise gerada pela Covid-19", como anunciou Scheller no início do debate. Nos termos de Geovani Freitas (2006, s/p), a violência simbólica é "tão ou mais cruel quanto a violência física". Diz o autor:

Concomitantemente às práticas de violência física que fazem parte da dinâmica cotidiana atual, opera-se uma outra forma de violência que, embora não se revele na sua forma imediata, perceptível à consciência e à sensibilidade das pessoas, é tão ou mais cruel quanto a violência física. Chamamos de violência simbólica ou violência doce os modos de sentir e de pensar que reproduzem e legitimam, na prática, valores classificatórios sobre o outro sem que sejam percebidos como tais. Neste sentido, há formas de dominação cristalizadas que se reproduzem quase que inconscientemente na sociedade, assumindo posição de verdades naturais que se impõem de forma irrefletida. Exemplo disto pode ser referido em relação aos lugares no mundo social-histórico do masculino em relação ao feminino, do adulto em relação à criança, do saber erudito em relação ao saber popular, entre outras formas de oposição cognitivas presentes no saber-fazer de nossas práticas sociais.

Nesse sentido, a violência simbólica que circula nas palavras de Benchimol participa de processos de legitimação e naturalização da injusta distribuição econômica brasileira. É importante ter em mente que temos o $9^{\circ}$ maior PIB do mundo, mas estamos entre os mais desiguais economicamente (NERI, 2019). Vejamos como a comunicabilidade da naturalização econômica se dá na sequência do discurso de Benchimol. Mais adiante na live, o presidente da XP comenta sobre a dificuldade de se manter a quarentena, a principal forma de se conter a pandemia, segundo especialistas e a OMS: "É um desafio você pedir que a população inteira fique presa em casa. Um terço da população vive de diária e se não trabalhar hoje não vai comer, no máximo, na semana que vem." $\mathrm{E}$ ainda argumenta que no orçamento do Estado brasileiro não há espaço para auxílios robustos que permitam a esse segmento da população se resguardar em casa.

No entanto, o presidente do Banco Central, Roberto Campos Neto, anunciou um pacote de medidas para socorrer os bancos que 
chega a R\$ 1,216 trilhão, ou 16,7\% do Produto Interno Bruto brasileiro (PIB). Na crise financeira global de 2008, o montante aplicado com o mesmo objetivo foi de R\$ 117 bilhões, 3,5\% do PIB, 10 vezes menor (BARBOSA; HESSEL, 2020). Segundo a economista Laura Carvalho (2020), as projeções sobre o auxílio emergencial de três meses dado aos trabalhadores que ficaram desempregados, informais ou precarizados apontam que o auxílio custou aproximadamente R\$ 155 bilhões, ou $2,1 \%$ do PIB. Fruto de pressão da sociedade civil, o auxílio emergencial ecoa a noção de renda básica, defendida pelo ex-senador Eduardo Suplicy desde os anos 1980 e atualmente empregada com grande êxito na Finlândia, Quênia, Canadá e algumas regiões dos Estados Unidos da América (ROQUE, 2018). Assim, a escolha de O Estado de S. Paulo de fazer lives apenas com "empresários e executivos" em sua discussão de economia na quarentena, deixando de lado o contraponto de vozes que defendem uma política econômica mais redistributiva, termina por atualizar a histórica perspectiva de que no orçamento governamental não há dinheiro para auxiliar os trabalhadores, mas sim os setores tradicionalmente beneficiados pelo governo.

Não podemos perder de vista que essas lives, como construções comunicáveis, são feitas para infectar, isto é, são projetadas para circular socialmente e produzir certa perspectiva de conhecimento sobre a economia e a constituição racial da sociedade. E os caminhos de entextualização (BAUMAN; BRIGGS, 1990) dos enunciados de Benchimol - isto é, sua descontextualização e posterior recontextualização como unidades autônomas - se dá em campos sociais cada vez mais digitais e controlados por algoritmos que, a serviço de plataformas como Facebook e Twitter, transformam likes e visualizações em valor de mercado. E assim como o vírus, que parece chegar cada vez mais perto de nós, as notícias se multiplicam quando alcançam grupos de WhatsApp familiares ou laborais, ganhando autoridade e poder crescente de infecção. Essas unidades entextualizadas muitas vezes se transformam em mensagens com frases curtas e de impacto, com ilustrações montadas com objetivo de conduzir certas interpretações. Anteriormente ao cenário digital das fake e junk news contemporâneas, a própria imprensa corporativa já se utilizava de recursos como esses, como no caso de manchetes impactantes que não revelavam o exato conteúdo proposicional da reportagem, mas ressaltavam aquilo que se queria transmitir de forma rápida e fixadora. Muitos leitores de jornais não liam mais que as manchetes. Mas, nas redes 
sociais, esse poder de comunicabilidade, em que gotículas de informação são passadas de pessoa a pessoa, se potencializa exponencialmente, atacando seus receptores com a mesma voracidade de um vírus atacando as células humanas. Rapidamente, uma verdade se constrói e se fixa, atualizando-se pela transmissão iterável de um texto em circulação.

Essa intensa circulação viral ativa crenças, ideologias e formas de ver o mundo hegemonizadas pela transmissão pandêmica de certas construções metapragmáticas do discurso - como necessidade econômica, por exemplo. É nesse cenário que vozes e mãos se levantam em luta de resistência. No vácuo deixado pela ausência do Estado com políticas públicas de combate à pandemia e à desigualdade, constrói-se a autoorganização. No Complexo do Alemão, no Rio de Janeiro, por exemplo, a ONG Voz da Comunidade se uniu ao Coletivo Papo Reto e ao Mulheres em Ação para formar o Gabinete de Crise do Complexo do Alemão, responsável por campanhas de esclarecimentos sobre como combater a pandemia da Covid 19. As ações do Gabinete se expandiram por meio de campanhas solidárias de arrecadação e distribuição de alimentos e água, dada a ineficiência de políticas públicas que suprissem as carências de renda e condições de moradia na favela. Campanhas emergenciais solidárias são efetivadas por grupos auto-organizados dentro das próprias comunidades faveladas e periféricas. $O$ enfrentamento não é só ao Covid 19, mas à desinformação e negligência estatal. Lives e vídeos circulam pelas redes sociais em plataformas como Youtube e Instagram, assim como nos carros de som que percorrem o bairro em campanhas emergenciais. A CUFA(Central Única das Favelas), que existe há mais de vinte anos, lançou a campanha "Doação Mães da Favela" com o intuito de ajudar às mulheres nesse momento de crise. Essa auto-organização é o antídoto ao veneno viral que circula há séculos, naturalizando mortes e desigualdade social. A crise econômica e sanitária mostrou, de maneira inquestionável, o fosso da desigualdade que direciona as políticas econômicas e prioridades do Estado, mas também expôs o potencial de luta e resistência dessas populações secularmente excluídas e seu poder de organização e de construir novas pautas que desafiam o discurso de ódio, o racismo de raça e classe. Como disse Preto Zezé, presidente da Cufa:

conectamos mais de cinco mil favelas, em 26 estados e Distrito Federal, tem gente do extremo Sul do Rio Grande Sul às tribos indígenas do Acre, indo de barco distribuindo cesta básica. Só que nós não estamos só distribuindo cesta básica, aí que tá, 
nós estamos fazendo com que a solidariedade, a relação, a vida comunitária, a coletividade seja mais contagiosa que o vírus. Esse é o pulo do gato.Na seção seguinte, continuaremos discutindo o processo de comunicabilidade da violência simbólica, desta vez elaborando sobre o processo desigual e violento de construção pictórica de Dilma Rousseff pelo Estadão, durante a crise política que culminou com o impeachment de uma presidenta eleita.

\section{Semiose da violência}

Pela primeira vez na história do Brasil, uma mulher ocupava o mais alto cargo do poder executivo. Dilma Rousseff, depois de participar ativamente dos governos Lula, estando a frente de dois ministérios (Minas e Energia, Casa Civil), elegeu-se presidenta em 2010. Em 2014, foi reeleita e, em 2016, sofreu impeachment.

Durante os seus dois mandatos presidenciais, especialmente no transcurso do processo de impeachment, Dilma foi capa de diversas publicações jornalísticas. Em muitas, foi acusada de pedaladas fiscais e de envolvimento em esquemas de corrupção. Em outras, foi exposta ao ridículo (DILMA..., 2013) e a cenas dantescas (CARUSO, 2015), enredada em atmosferas de solidão (A SOLIDÃO..., 2016) e de envelhecimento (GUERREIRO, 2015), associada à ideia de atraso (A MÁQUINA..., 2015), questionada quanto à sua performance de feminilidade e sexualidade (VIEIRA, 2015) e apontada como uma mulher dada a ataques de histeria e fúria (AS EXPLOSÕES..., 2016), além de ser apresentada como uma pessoa perigosa por conta de seu passado guerrilheiro (O PASSADO..., 2010). ${ }^{6}$ Em algumas dessas publicações,

\footnotetext{
${ }^{6} \mathrm{Na}$ capa da edição 2317 da revista Veja, publicada no dia 16 de setembro de 2015, cuja manchete é "Dilma pisou no tomate", a ex-presidenta é exposta ao ridículo. Em 2015, no dia 8 de março, data em que se comemora internacionalmente o dia da mulher trabalhadora, Chico, em sua charge, publicada em destaque na capa do jornal $O$ Globo, desenha Dilma a ponto de ser executada por um membro do Estado Islâmico. Na capa da revista Época, número 931 (edição especial do Impeachment), publicada no dia 16 de abril de 2016, cuja manchete é “A solidão de Dilma”, a líder do executivo é mostrada isolada. O jornal Folha de São Paulo, no dia 11 de março de 2015, publica narrativa noticiosa assinada por Gabriela Guerreiro cujo título era "Presidente do Senado ataca Planalto e diz que governo Dilma 'envelheceu'". Em dezembro de 2015, a manchete da edição 2456 da revista Veja, "A máquina do atraso de Dilma”, projeta Dilma como
} 
Dilma Rousseff era literal e multimodalmente atacada (ver BARONAS, 2015; CARDOSO, 2017; NEVES; NEVES, 2017; ZDEBSKYI; MARANHÃO; PEDRO, 2015).

Aqui, abordamos narrativas noticiosas ${ }^{7}$ (GONZALEZ, 2017) que constroem, exibem, incitam ou propagam cenas de violência simbólica, mais especificamente em sua feição semiótica, como aquela em que Dilma parecia arder na fogueira do Estadão (ver FIGURA 1). Essa narrativa, ao explorar ilusões óticas que determinadas objetivas fotográficas forjam, dá materialidade ao enunciado imagético proferido, performativamente criando aquilo que aparentemente apenas descreve: um ataque pirômano. Ao fazê-lo, combina diferentes recursos semióticos: afinal, toda narrativa noticiosa é multimodalmente urdida. Logo, a análise desse tipo de narrativa deve contemplar tanto os elementos lexicais como os imagéticos que dela fazem parte. Em outras palavras, há de se dedicar um olhar atento à relação léxico-imagética que se estabelece entre os elementos que a compõem.

Para dar conta de tal propósito, recorremos à noção de indexicalidade (SILVERSTEIN, 2003). Esse construto, cuja origem remete à noção de índice de Charles S. Peirce (2005), nos permite identificar como signos, ao serem mobilizados numa dada prática discursiva, conectam-se com significados que trafegam em escala mais ampla. Essa conexão indexical, por força da repetição, pode adquirir estabilidade, naturalizando certas correlações históricas de sentido. Observemos a imagem em questão:

atrasada. O artigo "Dilma e o sexo", publicado pela Época no dia 20 de agosto de 2015, questiona a sexualidade da ex-presidenta. A capa da edição 2417 da Isto é, publicada no dia 6 de abril de 2016, cuja manchete é "As explosões nervosas da presidente" constrói Dilma como uma mulher dada a ataques de fúria e histeria. A capa da edição 639 de Época, publicada no dia 16 de agosto de 2010, cuja manchete é "O passado de Dilma - Documentos inéditos revelam uma história que ela não gosta de lembrar: seu papel na luta armada contra o regime militar" apresenta a ex-presidenta como uma mulher perigosa por conta de seu passado guerrilheiro.

${ }^{7}$ Em linha com os estudos críticos do jornalismo, utilizamos, em lugar do termo 'notícia', a expressão 'narrativa noticiosa' para ressaltar o caráter narrativo e interpretativo desse tipo de produção (GONZALEZ, 2017; ALBUQUERQUE, 2000). Operamos, assim, numa chave que se afasta da distinção estanque entre 'fato' e 'opinião' e se aproxima de uma leitura performativa do jornalismo (RAJAGOPALAN, 2003). 
FIGURA 1 -O Estado de S. Paulo, 4 de maio de 2016.

\section{OESTADO DE S.PAULO}

Janot denuncia Lula na Lava Jato e pede investigação contra Dilma

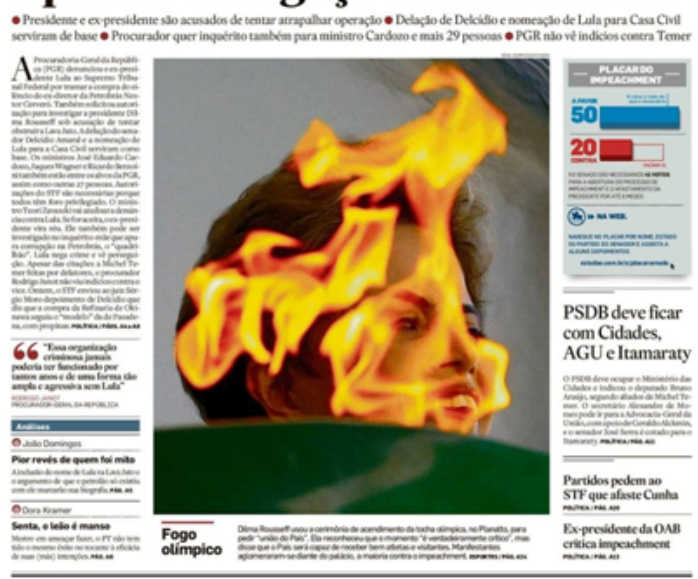

Fonte: O Estado de S. Paulo. Fotografia de Dida Sampaio/ Agência Estadão.

O Estado de S. Paulo, na capa da edição do dia 4 de maio de 2016, publicada durante o processo de impeachment movido contra a então presidenta, mostra Dilma aparentemente em chamas. $\mathrm{Na}$ foto, realizada por Dida Sampaio, o rosto de Dilma aparece através do fogo que emana da tocha olímpica. $\mathrm{Na}$ imagem, há o predomínio de duas cores: verde e amarelo. Esses índices cromáticos indiciam discursos nacionalistas que, desde as manifestações de junho de 2013, foram intensamente apropriados por grupos de direita para protestar contra o PT e pedir o impeachment da então presidenta (BECKER; CESAR; GALLAS; WEBER, 2016).

Uma breve análise do uso das cores pátrias na narrativa de capa em questão nos mostra como o Estadão endossa semioticamente o linchamento a que Dilma foi submetida. O amarelo, que abarca grande parte da imagem e aparece em destaque por conta de sua centralidade, provém do fogo que parece consumir Dilma. O verde, que ocupa a parte 
inferior da fotografia, colore a base em que está a tocha e chega encobrir o queixo de Dilma. Por seu formato ovalado assemelhar-se ao de um prato, uma das leituras possíveis que a imagem projeta é a de que a cabeça da então líder do executivo está sendo colocada a prêmio, o que acontece durante um cerimonial festivo: à ocasião, celebrava-se o acendimento da tocha olímpica. Eis aí dois pontos a serem considerados: o primeiro remete ao fato de que os índices mobilizados na imagem apontam para discursos orientadores de ordem religiosa que promoveram a caça às bruxas e as fizeram arder no fogo inquisitorial; o segundo diz respeito à contextualização desses índices imagéticos: por mais que a imagem não evidencie detalhes do cerimonial realizado, os índices lexicais que compõem a legenda "Fogo olímpico" contextualizam a cena. Nela, uma mulher é aparentemente lançada à fogueira numa cerimônia realizada em praça pública, lugar reservado, durante a Inquisição, à punição daqueles que eram vistos como uma ameaça à sociedade.

Evocar outro espaço-tempo, como a Inquisição, no caso em questão, nos ajuda a entender como a indexicalidade opera. De acordo com Silverstein (2006, p. 756-757, tradução nossa), o signo indexical, ou seja, o índice, tal como Peirce sinalizava, estabelece uma relação de "contiguidade espaço-temporal" entre o signo e aquilo a que este remete. Isto implica, dentre outras coisas, que índices, ao serem mobilizados em uma dada narrativa, sempre a extrapolam, sempre excedem seu contexto de enunciação (SILVERSTEIN, 2003) ao se conectarem com outros espaços-tempos. Essa extrapolação, quando aponta para a mesma direção repetidas vezes, acaba cristalizando associações indexicais (i.e., mulheres-bruxaria), fazendo com que certos sentidos sejam sociohistoricamente absorvidos (SILVERSTEIN, 2003), naturalizados.

Essa dimensão cronotópica-indexical da linguagem e da imagem também se faz notar na seção 3. Nela verificamos como o enunciado "sem vergonha" traz em si uma historicidade condensada (BUTLER, 1997) que aponta para o modo como juízos de valores conservadores são reciclados em uma prática situada, ecoando discursos sexistas que atuam em camadas da violência física - e não apenas simbólica - contra Cecília. De forma similar, o enunciado imagético aqui analisado opera: ao condenar Dilma Rousseff a arder no fogo inquisitório, a narrativa noticiosa do Estadão conecta-se a um espaço-tempo anterior, ao mesmo tempo em que atualiza sentidos socio-historicamente já absorvidos que naturalizam - e atualizam - modos de punir a "ousadia" de certas mulheres. 
Há de se ter em conta, além disso, que conforme discutimos na seção anterior, um processo comunicável de naturalização e legitimação está em curso aqui. Na narrativa do Estadão, o linchamento pirômano a que Dilma é exposta também pode ser interpretado como uma forma de frear avanços de certos sujeitos e tentativa de recuperar territórios. Mulheres, em lugar de ocupar a presidência da república, deveriam permanecer na esfera doméstica, desempenhando performances de belas e recatadas no lar.

Discursos que contribuíram para restringir a mulher ao âmbito privado e para subtrair-lhe protagonismo há muito tempo circulam (ZDEBSKYI; MARANHÃO; PEDRO, 2015). O mito grego indiretamente sugere isso ao propor uma clara divisão de tarefas: enquanto os homens se dedicariam a trabalhar fora, as mulheres ficariam em casa (SCHMITT-PANTEL, 2003). Tanto na tradição grega como na judaico-cristã, a mulher é criada como categoria secundária (SCHMITTPANTEL, 2003). E, desde Pandora e Eva, a figura feminina é associada à introdução do pecado e do mal no mundo. ${ }^{8}$ Logo, torna-se passível de ser punida. Durante a Inquisição, como sinaliza Federici (2019), basicamente só mulheres eram acusadas de bruxaria. Muitas foram lançadas à fogueira sob essa acusação.

Esses discursos, que levam à inferiorização, culpabilização ou punição da mulher, vêm de longa data. Além de atuarem na justificativa da violência de gênero, também instauram naturalizações de determinadas formas de subjetividade. Tais discursos, por se repetirem, atualizam-se. Não por casualidade, ainda hoje, mulheres continuam sendo associadas a incertezas, ambiguidades, oscilações e mistérios. Essa percepção, que remonta ao Iluminismo, projeta e reforça cisões. Enquanto a masculinidade era associada à precisão e solidez da ciência, a feminilidade era associada à imprecisão e instabilidade da emoção. De um modo geral, tudo o que era abominado por esse movimento, fundamentado na lógica, na superioridade da razão, na certeza e precisão da ciência, é sintetizado na figura feminina.

\footnotetext{
${ }^{8} \mathrm{Na}$ mitologia grega, a mulher chega a ser encarada como um castigo. Zeus oferta Pandora a um mortal (Epimeteu) como forma de punir a humanidade pelo roubo do fogo. Ela, portanto, não é criada para fazer companhia ao homem, mas para levar a cabo uma vingança. Em contrapartida, "não se sabe como nem em que etapa os homens passaram a existir, eles simplesmente estão presentes, são uma categoria coletiva" (SCHMITT-PANTEL 2003, p. 131).
} 
Os ideais iluministas, segundo Bauman e Briggs (2003), ganham imensa força no século XIX, graças à visada filosófica de autores como Locke e Bacon. Os dois contribuíram decisivamente para que o projeto da Modernidade Iluminista se concretizasse, destacando a importância de se operar com uma concepção de linguagem - e sociedade - livre de ambiguidades. Essa forma de se conceber a linguagem e a produção do conhecimento como algo neutro, imparcial, universal e livre de ruídos ainda ressoa nos dias atuais (BERNARDINO-COSTA; GROSFOGUEL, 2016; MOITA LOPES, 2013). Influenciou, dentre outras coisas, a percepção de que a imprensa, inventada no século XV e impulsionada pela revolução industrial, seria um aparato enunciador da verdade (BAHIA, 2009). ${ }^{9} \mathrm{O}$ mesmo se pode dizer da fotografia, que surge na primeira metade do século XIX, também sob os ecos da Modernidade e da revolução industrial. Segundo Fontcuberta (2011), essa invenção seria um emblema da sociedade industrial que a produziu. Essa nova tecnologia emerge como índice de credibilidade referencial. Essa ideologia referencialista impregnou a fotografia a ponto de Barthes (1984, p. 72) afirmar que "a essência da fotografia consiste em ratificar o que ela representa".

Um dos autores que mais contribuiu para pôr em xeque essa ideologia de linguagem foi John L. Austin (1962). Sua teoria sobre os atos de fala evidencia que a linguagem - o mesmo vale para a imagem (GONZALEZ, 2017) - não tem por função descrever ou representar uma dada realidade que existiria a priori. A linguagem age ativamente no mundo social, performativamente criando aquilo que parece apenas descrever. O modo como o/a fotógrafo/a constrói a imagem evidencia que linguagem e imagem não descrevem estados de coisa, mas os instauram. Dilma, de fato, não estava ardendo no fogo, por mais que a imagem sugira algo assim. Logo, o fotojornalista, ao buscar um determinado ângulo para a construção dessa ilusão ótica, não se limitaria a "representar" uma realidade de forma fidedigna, a simplesmente "transmitir" informação. $\mathrm{O}$ fotojornalista e a equipe editorial do jornal, ao enquadrarem a então presidenta na imagem analisada, lançam Dilma às chamas. Em outras palavras, performativamente, criam aquilo que descrevem.

\footnotetext{
${ }^{9}$ Gutenberg inventa, no século XV, uma máquina (a prensa móvel) que permitiria a impressão gráfica. No século XVIII, embalada pela revolução industrial e pelo crescimento das urbes, esta máquina seria usada para a impressão de jornais e alavancaria a atividade jornalística (BAHIA, 2009).
} 
Outro fato a ser considerado é que a fotografia em questão carece de ambientação, não havendo informação detalhada de fundo nem projeção de linhas de fuga. Pode-se vislumbrar aí uma metáfora do que estaria acontecendo com a então presidenta: assim como os índices imagéticos sugerem, ela estaria encurralada. Essa leitura é reforçada pelos índices lexicais mobilizados. O título "Janot denuncia Lula na Lava Jato e pede investigação contra Dilma", em destaque acima da fotografia, colabora para criar um clima de cerco que se fecha. Curiosamente, o último dos subtítulos, abaixo do título principal, afirma não haver indícios contra o então vice-presidente ("PGR não vê indícios contra Temer"). Numa leitura pragmática, não podemos perder de vista os índices de pertencimento em questão. Estamos não apenas diante de um processo de impeachment que colocaria Temer no lugar de Dilma, mas também de um processo político que substituiria uma mulher - vista como desequilibrada, autoritária e de passado guerrilheiro - por um homem branco, heterossexual, cisgênero e rico. O perfil racial e econômico de Temer, iconizado pela maioria daqueles que o absolveram, desfruta dos privilégios que hegemonias interseccionadas de gênero, raça, classe e sexualidade lhe asseguram. Temer, em outras palavras, ocupa o mais alto patamar da escala social. Ele personifica o status quo. Dilma, apesar dos privilégios que sua cor, cisgeneridade e classe social lhe ofertam, não pertence ao mesmo clube. É vista como uma intrusa, como uma ameaça às hegemonias instituídas, como uma mulher que se recusa a desempenhar a performance de "categoria secundária" (SCHMITT-PANTEL, 2003), personificada, a posteriori, na figura de Marcela Temer, predicada - e exaltada - pela mídia corporativa como "bela, recatada e do lar".

Para além da condução da política econômica do país, o fato de Dilma ser mulher, ao que parece, incomodou grupos que historicamente têm se favorecido dos diferentes tipos de desigualdade que assolam o país. A despeito de seu histórico de luta e sobrevivência, Dilma Rousseff, que foi presa e torturada durante a violenta ditadura brasileira, tal como as bruxas de outrora, foi consumida pelas chamas inquisitoriais contemporâneas. O Estadão o fez combinando índices lexicais e imagéticos que, na narrativa noticiosa de capa analisada, criaram as condições de possibilidade - ou de felicidade (AUSTIN, 1962) - para que a enunciação imagética ganhasse a força de ferir. Força esta que inexiste no vácuo de um proferimento isolado. Sobre a violência na linguagem, Butler (1997, p. 51) foi enfática ao concluir: "nenhum termo 
ou enunciado pode funcionar performativamente sem a acumuladora e dissimuladora historicidade da força".

Do mesmo modo que a acumuladora e dissimuladora historicidade da força dá materialidade à violência, atos de resistência podem se insurgir contra essa sedimentação, mesmo em cenários pouco favoráveis. Em meio à crise financeira, motivada em grande parte pela entrada de novos players no mercado da informação (buscadores, blogs, redes sociais etc.), e à crise de credibilidade que a mídia corporativa enfrenta, dois fenômenos, dentre tantos outros, ganharam forma: a proliferação de sites de jornalismo independentes (por exemplo: Mídia Ninja, Jornalistas livres, A Pública, AzMina ${ }^{10}$ ) e projetos como o ObjETHOS ${ }^{11}$ (Observatório de Ética Jornalística). De diferentes propósitos e alcances, essas iniciativas constituem uma forma de resistência, seja por funcionarem à margem dos grandes conglomerados midiáticos, seja por sua proposta deontológica. Enquanto a Mídia Ninja funciona como uma rede colaborativa de produção e distribuição de informação e o coletivo Jornalistas Livres prima pela pluralidade de abordagens, sites como A Pública e AzMina dão protagonismo às mulheres. O primeiro é uma agência de jornalismo investigativo fundada por mulheres repórteres; o segundo, uma revista digital que visa combater a violência contra a mulher. Como vimos nas seções 1 e 3 , desse tipo de violência não se veem livres nem mulheres como Cecília nem a autoridade máxima do poder executivo brasileiro. Diferentes ataques à ex-presidenta Dilma Rousseff, por certo, inspiraram o ObjETHOS a publicar textos sobre a (falta de) ética jornalística de alguns dos principais veículos de informação do país. Num deles, Moretzsohn (2016) se debruça sobre a mesma capa que Gonzalez analisa e, referenciando Lima (2014), lança um alerta: tais práticas não afetam 'apenas' a credibilidade de pessoas públicas e de certas instituições, acabam mermando a credibilidade da própria democracia. Daí a importância de iniciativas como as aqui mencionadas, as quais, como diz a canção, ${ }^{12}$ demonstram ser possível acreditar em flores vencendo canhões.

\footnotetext{
${ }^{10}$ Mídia Ninja. Disponível em: https:/midianinja.org/. Acesso: 27 ago. 2020. Jornalistas Livres. Disponível em: https://jornalistaslivres.org/. Acesso: 27 ago. 2020. Pública. Disponível em: https://apublica.org/. Acesso: 27 ago. 2020. AzMina. Disponível em: https://azmina.com.br/. Acesso: 27 ago. 2020.

${ }^{11}$ ObjETHOS. Disponível em: https://objethos.wordpress.com/. Acesso: 27 ago. 2020.

${ }^{12}$ Pra não dizer que não falei de flores (Caminhando), autor: Geraldo Vandré, 1968.
} 


\section{Considerações finais: costurando os cenários de violência e resistência}

Este artigo é resultado da colaboração de duas autoras e dois autores que mobilizaram sua pesquisa situada sobre linguagem e violência, de forma a produzir sentido e nuance sobre algumas dimensões da violência em três cenários particulares: a narrativa de uma vítima da violência, a violência simbólica contida numa live do Estadão e a violência explicitamente visual produzida pelo mesmo jornal.

Primeiramente, a partir da etnografia de Arcanjo, demonstramos que a violência, em suas feições física e simbólica, está enredada em escalas - em dimensões do discurso e da vida social (CARR; LEMPERT, 2016). Mostramos o peso que ideologias persistentes sobre desigualdade de gênero, bem como certos meandros burocráticos no encaminhamento de denúncias sobre parceiros violentos, podem impedir o acesso de vítimas da violência a seus direitos. Podem ainda amplificar a violência simbólica que essas vítimas já sofrem, num ciclo de legitimação do qual a violência física também participa.

Em seguida, no contexto da infecciosidade de narrativas durante a pandemia do novo coronavírus, que afeta todo o planeta, discutimos a circulação de enunciados violentos sobre moradores de favelas, grupo marcadamente racializado e minoritarizado no país. O ciclo de legitimação de classe e de naturalização de uma política econômica desigual, epitomizado pela fala de um rico empresário brasileiro em uma live do Estadão, se dissemina numa cartografia comunicável que mapeia o fluxo de capitais, palavras e corpos de acordo com desigualdades persistentes e com ideologias sobre a viabilidade de certas vidas e a indiferença a outras.

Depois, analisamos outro traço da comunicabilidade da violência simbólica também produzida pelo Estadão. A partir do estudo de uma capa em que Dilma Rousseff, a única mulher que chegou à presidência do Brasil, é aparentemente incendiada pela pira olímpica, demonstramos como elementos da histórica desigualdade de gênero no Brasil e de discursos mais gerais que situam mulheres como pertencentes à esfera privada, como desequilibradas ou como bruxas se acumularam naquela representação imagética da cabeça de Dilma sendo servida em chamas sobre um prato verde. A dimensão sutil e insidiosa da violência simbólica naquela capa foi enfocada em nosso estudo a partir de uma decomposição 
dos elementos do registro fotográfico, bem como de manchetes que, compondo o cotexto da imagem, apontam para a inviabilidade de Dilma na presidência e para a suposta inocência de Michel Temer, o então vicepresidente que se movimentava para assumir o executivo.

Ancorados numa teoria mais ampla da ação na linguagem - i.e., a performatividade -, os aspectos teóricos que enfatizamos em cada contexto específico (escala, comunicabilidade e indexicalidade) podem ser entendidos como elementos participantes da violência que circulou nos três contextos. Na delegacia do interior do Rio de Janeiro, por exemplo, Cecília foi atingida não apenas pela violência que foi escalada para o espaço-tempo do patriarcado e dos valores "tradicionais", que culpabilizam mulheres pela violência de seus companheiros, mas também pela circulação viral e insidiosa (i.e., a comunicabilidade) desse projeto escalar e pelo "apontar" (i.e., a indexicalidade) desse projeto para modos de contextualizar a linguagem e o pertencimento identitário. A escala, a comunicabilidade e a indexicalidade, como processos semióticos, participam da produção da violência na linguagem. Eles dizem respeito à percepção e ao enquadramento (i.e., escala), à circulação e às ideologias linguísticas correlatas (i.e., comunicabilidade) e à semiotização e contextualização (i.e., indexicalidade) da significação da violência.

Para concluir, gostaríamos de chamar atenção para o fato de que essas facetas escalares, comunicáveis e indexicais da violência, a qual atinge sobretudo sujeitos racializados e generificados no Brasil, são também contestadas por aqueles que são afetados pela violência dos signos. No primeiro caso em tela, apontamos que o ato de narrar a violência num contexto de efetiva escuta e identificação tem efeitos contrários à destruição da violência. Cecília conversa com Arcanjo sabendo que terá um interlocutor que se interessa em ouvir seu sofrimento; sobretudo, ela sabe que sua narrativa se transformará em elementos de um estudo que pode se traduzir em um entendimento de como a violência circula e, possivelmente, fornecer elementos para o efetivo combate à violência. Na mesma seção, aludimos ao trabalho de Ostermann (2003) e Ostermann e Costa (2012), que comparam padrões interacionais de uma Delegacia da Mulher e de centros feministas de apoio a vítimas da violência. A conclusão que as autoras chegam - de que uma orientação feminista vem acompanhada de uma postura solidária na interação com mulheres afetadas pela violência de gênero - sinaliza para uma importante escala da resistência à violência: ao oferecer uma 
postura ativa na co-construção de enunciados sobre o trauma e caminhos institucionais para o encaminhamento das denúncias, as triagistas do CIV-Mulher dão um exemplo claro de como agir linguisticamente no combate à violência contra a mulher.

Embora tenhamos dado mais ênfase à comunicabilidade da violência nos canais de $O$ Estado de $S$. Paulo (i.e., Youtube e capa do jornal impresso) do que na resistência à violência que circula nos circuitos do jornal, gostaríamos de salientar que Charles Briggs entende que o processo de comunicabilidade, além de ser imbuído de poder e modelador de visões de mundo, é contestável. Diz o autor: "apesar de sua base em desigualdades materiais e institucionais, mapas comunicáveis adquirem efeitos à medida que pessoas respondem aos modos em que textos buscam interpelá-las" (BRIGGS, 2007, p. 556, tradução nossa). Algumas das respostas, aponta o autor, podem ser realizadas "pela recusa [das pessoas] a se localizarem nas posições oferecidas por esses textos, pela revisão crítica de tais posições ou pela rejeição completa dessas construções comunicáveis" (p. 556). Assim, apontamos para o importante trabalho do Gabinete de Crise do Complexo do Alemão, um agrupamento de coletivos de moradores dessa favela interessado em tornar a autoorganização das periferias em política de sobrevivência dos moradores, num território em que o Estado se faz presente sobretudo em sua faceta penal e policial. A CUFA vem fazendo um trabalho semelhante, atingindo muitas outras favelas do Brasil. Além disso, no universo do jornalismo não-corporativo, coletivos de comunicação como Mídia Ninja, Jornalistas Livres, A Pública e AzMina vêm oferecendo modelos comunicáveis alternativos àqueles oferecidos pelos veículos corporativos.

As iniciativas da sociedade civil em resistência à violência física e simbólica são muito mais numerosas e variadas do que as que listamos acima. Acreditamos, assim, que estudos adicionais que delineiem as escalas e a comunicabilidade da resistência à violência são fundamentais para a produção de sociabilidades menos desiguais e violentas no mundo contemporâneo. 


\section{Declaração de contribuição de cada autor}

Todos os quatro autores participaram do planejamento e redação do presente manuscrito. Alvaro Arcanjo realizou a pesquisa de campo na qual se baseia a seção 3, por ele redigida. Anabella Rocha realizou a pesquisa documental na qual se baseia a seção 4, por ela redigida. Clarissa Gonzalez realizou a pesquisa documental na qual se baseia a seção 5, por ela redigida. Daniel Silva redigiu a introdução, seção 2 e conclusão. Todos os autores contribuíram com as seções dos demais colegas, seja por meio de revisão, de redação de alguns excertos ou de colaboração em seu desenho.

\section{Referências}

ALBUQUERQUE, A. A narrativa jornalística para além dos faits-divers. Lumina, Juiz de Fora, v. 3, n. 2, p. 69-91, 2000.

AUSTIN, J. L. How to Do Things with Words. Oxford: Oxford University Press, 1962.

A MÁQUINA do atraso de Dilma. Veja, São Paulo, 16 dez. 2015. Capa. A SOLIDÃO de Dilma. Época, São Paulo, 16 abr. 2016. Capa.

AS EXPLOSÕES nervosas da presidente. Isto é, São Paulo, 6 abr. 2016. Capa.

BAHIA, J. História da imprensa brasileira. Jornal, história e técnica. Rio de Janeiro: Mauad, 2009.

BAKHTIN, M. As formas do tempo e do cronotopo. In: Teoria do Romance II. Tradução, posfácio e notas de Paulo Bezerra; organização da edição russa de Serguei Botcharov e Vadim Kójinov. São Paulo: Editora 34, 2018. p. 11-236.

BARBOSA, M.; HESSEL, R. Pacote anunciado pelo governo deve liberar R\$ 1,2 trilhão aos bancos. Correio Braziliense, Brasília, 24 mar. 2020. Disponível em: https://www.correiobraziliense.com.br/app/noticia/ economia/2020/03/24/internas_economia,836224/pacote-anunciadopelo-governo-deve-liberar-r-1-2-trilhao-aos-bancos.shtml. Acesso em: 9 jun. 2020. 
BARONAS, R. L. A (des)ordem da imagem na comunicação política brasileira: possibilidades analíticas a partir da noção discursiva de relações intercenográficas. Linguagem em (Dis)curso, Tubarão, SC, v. 15, n. 3, p. 401-413, 2015. DOI: https://doi.org/10.1590/1982-4017$150304-2015$

BARTHES, R. A câmara clara: notas sobre a fotografia. Rio de Janeiro: Nova Fronteira, 1984.

BAUMAN, R.; BRIGGS, C. Poetics and Performances as Critical Perspectives on Language and Social Life. Annual Review of Anthropology, Palo Alto, CA, v. 19, n. 1, p. 59-88, 1990. DOI: https:// doi.org/10.1146/annurev.an.19.100190.000423

BAUMAN, R.; BRIGGS, C. Voices of Modernity: Language Ideologies and the Politics of Inequality. Cambridge: Cambridge University Press, 2003. DOI: https://doi.org/10.1017/CBO9780511486647

BECKER, C.; CÉSAR, C. M.; GALLAS, D.; WEBER, M. H. Manifestações e votos sobre impeachment de Dilma Rousseff na primeira página de jornais brasileiros. ALAIC - Revista Latinoamericana de Ciencias de la Comunicación, São Paulo, v. 13, n. 24, p. 96-113, 2016.

BERNADINO-COSTA, J.; GROSFOGUEL, R. Decolonialidade e perspectiva negra. Revista Sociedade e Estado, Brasília, v. 31, n. 1, p. 15-24, 2016. DOI: https://doi.org/10.1590/S0102-69922016000100002

BLOMMAERT, J. Chronotopes, Scales, and Complexity in the Study of Language in Society. Annual Review of Anthropology, Palo Alto, CA, v. 44, p. 105-116, 2015. DOI: https://doi.org/10.1146/annurevanthro-102214-014035

BOURDIEU, P. Language \& Symbolic Power. Cambridge: Harvard University Press, 1991.

BOURDIEU, P. The Field of Cultural Production: Essays on Art and Literature. New York: Columbia University Press, 1993.

BOURDIEU, P. A dominação masculina. 9. ed. Rio de Janeiro: Bertrand Brasil, 2010.

BRASIL. Presidência da República. Casa Civil. Subchefia para Assuntos Jurídicos. Lei $\mathrm{n}^{\mathrm{o}}$ 11.340, de 7 de agosto de 2006. Diário Oficial da União, Brasília, DF, 7 ago. 2006. 
BRASIL. Ministério da Saúde. COVID 19 no Brasil. 2020a. https:// susanalitico.saude.gov.br/extensions/covid-19_html/covid-19_html.html. Acesso em: 30 ago. 2020.

BRASIL. Painel Coronavírus do Ministério da Saúde. 2020b. Disponível em: https://covid.saude.gov.br/. Acesso em 11 jun. 2020.

BRIGGS, C. Communicability, Racial Discourse, and Disease. Annual Review of Anthropology, Palo Alto, CA, v. 34, p. 269-291, 2005. DOI: https://doi.org/10.1146/annurev.anthro.34.081804.120618

BRIGGS, C. Anthropology, Interviewing, and Communicability in Contemporary Social Life. Current Anthropology, Chicago, v. 48, n. 4, p. 551-580, 2007. DOI: https://www.https://doi.org/10.1086/518300

BRIGGS, C. On Virtual Epidemics and the Mediatization of Public Health. Language \& Communication, [S.l.], v. 31, n. 3, p. 217-228, 2011. DOI: https://doi.org/10.1016/j.langcom.2011.03.003

BROWN, P.; LEVINSON, S. Politeness: Some Universals in Language Usage. Cambridge: Cambridge University Press, 1987. DOI: https://doi. org/10.1017/CBO9780511813085

BUTLER, J. Excitable Speech: A Politics of the Performative. London: Routledge, 1997.

CALDEIRA, T. City of Walls. Crime, Segregation and Citizenship in São Paulo. Berkeley: University of California Press, 2000.

CARDOSO, V. G. "As explosões nervosas da presidente": uma análise do processo de impeachment de Dilma Rousseff na revista semanal Isto é. In: SEMINÁRIO INTERNACIONAL FAZENDO GÊNERO, 11., WOMEN'S WORLD CONGRESS, 13th., Florianópolis, 2017. Anais [...]. Florianópolis: UFSC, 2017. Disponível em: http://www. en.wwc2017.eventos.dype.com.br/resources/anais/1496529401 ARQUIVO_VivyaneGarbeliniCardoso.pdf. Acesso em: 10 jun. 2020.

CARR, S.; LEMPERT, M. (org.). Scale: Discourse and Dimensions of Social Life. Berkeley: University of California Press, 2016. DOI: https:// doi.org/10.1525/9780520965430

CARUSO, C. Charge do Chico. O Globo, Rio de Janeiro, 8 mar. 2015. Capa. 
CARVALHO, L. Governo e economia. In: SIMPÓSIO DIREITAS BRASILEIRAS, 2., 2020, Campinas. [Mesa: "Governo e economia", com participação de Marcos Nobre e Sávio Cavalcante]. Disponível em: https://www.youtube.com/watch?v=-bZ19AkrFhQ. Acesso em: 9 jun. 2020 .

DAS, V. Life and words: Violence and the descent into the ordinary. Berkeley: University of California Press, 2007.

DE FINA, A. Identity in Narrative: A Study of Immigrant Discourse. Amsterdam: John Benjamins, 2003. DOI: https://doi.org/10.1075/sin.3

DE LARA, B. et al. Meu amigo secreto: feminismo além das redes. Rio de Janeiro: Edições de Janeiro, 2016.

DERRIDA, J. Assinatura acontecimento contexto. Trad. Joaquim Torres Costa e Antônio M. Magalhães. In: . Margens da filosofia. Campinas. Papirus. 1991. p. 349-373.

DILMA pisou no tomate. Veja, São Paulo, 17 abr. 2013. Capa.

DURANTI, A. Linguistic Anthropology. Cambridge: Cambridge University Press, 1997. DOI: https://doi.org/10.1017/CBO9780511810190

ESTADÃO. São Paulo, 4 mai. 2016. Capa

ESTADÃO. "Estadão" faz entrevista ao vivo com o presidente da XP Investimentos. 2020. Disponível em: https://www.youtube.com/ watch? $\mathrm{v}=\mathrm{oQYh} 2 J \mathrm{Kx}-\mathrm{wc}$. Acesso em: 9 jun. 2020.

FABRÍCIO, B. F. Narrativização da experiência: o triunfo da ordem sobre o acaso. In: MAGALHÃES, I.; CORACINI, M. J.; GRIGOLETTO, M. (org.). Práticas identitárias: língua e discurso. São Carlos, Claraluz, 2006. p. 191-210.

FEDERICI, S. Mulheres e caça às bruxas. São Paulo, Boitempo, 2019.

FONTCUBERTA, J. La cámara de Pandora. La fotografi@ después de la fotografía. Barcelona: Gustavo Gili, 2011.

FREITAS, G. Viver pela metade. O Povo, Fortaleza, 7 out. 2006.

FREUD, S. Além do princípio do prazer. Trad. P. C. Souza. In:

Obras Completas de Sigmund Freud. São Paulo: Companhia das Letras, 2010. v. 14, p. 161-239. 
GOFFMAN, E. On Face-Work: An Analysis of Ritual Elements in Social Interaction. Psychiatry: Journal for the Study of Interpersonal Processes, Washington, DC, v. 18, n. 3, p. 213-231, 1955. DOI: https://doi.org/10.1 080/00332747.1955.11023008

GONZALEZ, C. Foto-grafia: a monstrualização de performances de gênero não binárias. Düsseldorf: NEA: Novas Edições Acadêmicas, 2017.

GONZALEZ, C.; MOITA LOPES, L. P. da. The Maternity Dispositif in All About My Mother: Entextualization and Scalar Processes. Alfa: Revista de Linguística, Assis, v. 64, n. 1, p. 1-27, 2020. DOI: https://doi. org/10.1590/1981-5794-e11313

GUERREIRO, G. Presidente do Senado ataca Planalto e diz que Dilma envelheceu. Folha de S. Paulo, São Paulo, 11 mar. 2015. Disponível em: https://www1.folha.uol.com.br/poder/2015/03/1601243-presidentedo-senado-ataca-planalto-e-diz-que-governo-dilma-envelheceu.shtml. Acesso em: 11 jun. 2020.

HANKS, W. Língua como prática social: das relações entre língua, cultura e sociedade a partir de Bourdieu e Bakhtin. São Paulo: Cortez, 2008.

IBGE. 2019. Disponível em: https://biblioteca.ibge.gov.br/visualizacao/ livros/liv101681_informativo.pdf; https:/www.ibge.gov.br/estatisticas/ sociais/populacao/ 25844-desigualdades-sociais-por-cor-ou-raca. $\mathrm{html} ?=\& \mathrm{t}=$ publicacoes. Acesso em: 15 maio 2020.

LATOUR, B.; WOLGAR, S. A vida de laboratório: a produção dos fatos científicos. Rio de Janeiro: Relume Dumará, 1997.

LEVI, P. É isto um homem? Rio de Janeiro: Rocco, 1988.

LIMA, V. A. de. Imprensa em questão. A capa do 'Correio Braziliense'. Observatório da Imprensa, Campinas, ed. 815, 9 set. 2014. Disponível em: http://www.observatoriodaimprensa.com.br/imprensa-em-questao/_ ed815_a_capa_do_correio_braziliense/.Acesso em: 27 ago. 2020.

LOPES, L. et al. Letramentos de sobrevivência: costurando vozes e histórias. In: LOPES, A. C.; FACINA, A.; SILVA, D. N. (org.). Nó em pingo d'água: sobrevivência, cultura e linguagem. Rio de Janeiro: Mórula; Florianópolis: Insular, 2019. p. 31-57. 
MACCORD, M.; SOUZA, R. Trabalhadores livres e escravos. In: SCHWARCZ, L.; GOMES, F. (org.). Dicionário da Escravidão e Liberdade 50 textos críticos. São Paulo: Companhia das Letras, 2018. p. 420-426.

MALKKI, L. Purity and Exile: Violence, Memory, and National Cosmology Among Hutu Refugees in Tanzania. Chicago; London: The University of Chicago Press, 1995. DOI: https://doi.org/10.7208/ chicago/9780226190969.001.0001

MEY, J. Pragmatics: An Introduction. London: Blackwell, 2001.

MICHAELIS. Dicionário de português brasileiro. 2020. Disponível em: https://michaelis.uol.com.br. Acesso em: 8 jun. 2020.

MOITA LOPES, L. P. (org.). Português no século XXI. Cenário geopolítico e sociolinguístico. São Paulo: Parábola, 2013.

MOITA LOPES, L. P.; FABRÍCIO, B. F.; GUIMARÃES, T. F. Scaling Queer Performativities of Genders in Sexualities in the Periphery of Rio de Janeiro in Digital and Face-to-Face Semiotic Encounters. In: KROON, S.; SWANENBERG, J. (org.). Language and Culture on the Margins. New York: Routledge, 2019. p. 127-144. DOI: https://doi. org/10.4324/9781351244350-8

MORETZSOHN, S. D. Ponto de vista: A bruxa na fogueira do Estadão, uma imagem e seus símbolos. ObjETHOS, Florianópolis, 5 maio 2016. Disponível em: https:/objethos.wordpress.com/2016/05/05/ponto-devista-a-bruxa-na-fogueira-do-estadao-uma-imagem-e-seus-simbolos. Acesso em: 27 ago. 2020.

NERI, M. A escalada da desigualdade: qual foi o impacto da crise sobre a distribuição da renda e da pobreza? Rio de Janeiro: FGV, 2019. Disponível em: https://cps.fgv.br/desigualdade. Acesso em: 9 jun. 2020.

NEVES, R.A.; NEVES, H. A. A representação da "mulher descontrolada" na capa da revista Isto é que retratou a presidenta Dilma "gritando". In: SEMINÁRIO INTERNACIONAL FAZENDO GÊNERO, 11., WOMEN'S WORLD CONGRESS, 13th., Florianópolis, 2017. Anais [...]. Florianópolis: UFSC, 2017.

O PASSADO de Dilma. Época, São Paulo, 16 ago. 2010. Capa. 
OSTERMANN, A. Communities of Practice at Work: Gender, Facework and the Power of Habitus at an All-Female Police Station and a Feminist Crisis Intervention Center in Brazil. Discourse \& Society, [S.l.], v. 4, n. 4, p. 473-505, 2003. DOI: https://doi.org/10.1177/0957926503014004004 OSTERMANN, A; COSTA, C. Gender and Professional Identity in Three Institutional Settings in Brazil: The Case of Responses to Assessment Turns. Pragmatics, [S.l.], v. 22, n. 2, p. 203-230, 2012. DOI: https://doi. org/10.1075/prag.22.2.02ost

OXFORD. Oxford English Dictionary. 2020. Disponível em: https:// www.oed.com. Acesso em: 8 jun. 2020.

PEIRCE, C. Semiótica. São Paulo: Perspectiva, 2005.

RAJAGOPALAN, K. Por uma linguística crítica: linguagem, identidade e a questão ética. São Paulo: Parábola, 2003.

RAJAGOPALAN, K. A nova pragmática: fases e feições de um fazer. São Paulo: Parábola, 2010.

ROQUE, T. Por causa de robôs, ideia de renda básica universal ganha mais adeptos. Folha de S. Paulo. São Paulo, 17 fev. 2018. Disponível em: https://www1.folha.uol.com.br/ilustrissima/2018/02/por-causa-de-robosideia-de-renda-basica-universal-ganha-mais-adeptos.shtml. Acesso em: 8 jun. 2020.

SAFFIOTI, H. Gênero, patriarcado, violência. São Paulo: Expressão Popular, 2004.

SCARRY, E. The Body in Pain: The Making and Unmaking of the World. Oxford: Oxford University Press, 1987.

SCHMITT-PANTEL, P. "A criação da mulher": um ardil para a história das mulheres? In: MATOS, M. I.; SOIHET, R. (org.). O corpo feminino em debate. São Paulo, Editora da Unesp, 2003. p. 129-156.

SELIGMANN-SILVA, M. O local do testemunho In: COELHO, F.; MAGALHÃES, M.; CÊRA, F. (org.). Literatura. Rio de Janeiro: FUNARTE, 2017. p. 249-268.

SILVA, D. Pragmática da violência: o nordeste na mídia brasileira. Rio de Janeiro: 7 Letras, 2012. 
SILVA, D. Investigating Violence in Language: An Introduction. In: . Language and Violence: Pragmatic Perspectives. Amsterdam; Philadelphia: John Benjamins Publishing Company, 2017. p. 1-29. DOI: https://doi.org/10.1075/pbns.279

SILVERSTEIN, M. Metapragmatic discourse and metapragmatic function. In: LUCY, J. (org.). Reflexive Language: Reported Speech and Metapragmatics. Cambridge: Cambridge University Press, 1993. p. 3358. DOI: https://doi.org/10.1017/CBO9780511621031.004

SILVERSTEIN, M. Indexical Order and the Dialectics of Sociolinguistic Life. Language \& Communication, [S.l.], v. 23, n. 3-4, p. 193-229, 2003. DOI: https://doi.org/10.1016/S0271-5309(03)00013-2

SILVERSTEIN, M. Pragmatic Indexing. In: MEY, J. L. Concise Encyclopedia of Pragmatics. London: Elsevier, 2006. p. 756-759. DOI: https://doi.org/10.1016/B0-08-044854-2/00381-3

STRATHERN, M. Partial Connections. Walnut Creek: AltaMira Press, 2004.

VERAS, V. Verdade em tradução: um testemunho da dor das palavras. Trabalhos em Linguística Aplicada, Campinas, v. 50, n. 2, p. 459-478, 2011. DOI: https://doi.org/10.1590/S0103-18132011000200014

VÍDEO "Na favela, o Estado já é mínimo" - conversa com Preto Zezé. Canal Henry Bugalho. Disponível em: https://youtu.be/1o7WEvPBMu8. Acesso em: 29 ago. 2020.

VIEIRA, J. L. Dilma e o sexo. Época, São Paulo, 20 ago. 2015. Disponível em: http://epoca.globo.com/vida/romance-urbano/joao-luizvieira/noticia/2015/08/dilma-e-o-sexo.html. Acesso em: 9 jun. 2020.

ZDEBSKYI, J. F.; MARANHÃO, E. M de A.; PEDRO, J. M. A histérica e as belas, recatadas e do lar: misoginia à Dilma Rousseff na concepção das mulheres como costelas e dos homens como cabeça da política brasileira. Espaço e Cultura, Rio de Janeiro, v. 38, p. 225-250, 2015. DOI: https:// doi.org/10.12957/espacoecultura.2015.29077 